\title{
Correction to: Happily entangled: prediction, emotion, and the embodied mind
}

\author{
Mark Miller $^{1}$ (D) Andy Clark ${ }^{1}$
}

Published online: 20 June 2019

(c) The Author(s) 2019

\section{Correction to: Synthese (2018) 195:2559-2575 https://doi.org/10.1007/s11229-017-1399-7}

In the original publication, funding information was missing:

Andy Clark was supported by ERC Advanced Grant 692739 (XSPECT_Expecting Ourselves-Embodied Prediction and the Construction of Conscious Experience).

Open Access This article is distributed under the terms of the Creative Commons Attribution 4.0 International License (http://creativecommons.org/licenses/by/4.0/), which permits unrestricted use, distribution, and reproduction in any medium, provided you give appropriate credit to the original author(s) and the source, provide a link to the Creative Commons license, and indicate if changes were made. The Creative Commons Public Domain Dedication waiver (http://creativecommons.org/publicdomain/zero/1.0/) applies to the data made available in this article, unless otherwise stated.

Publisher's Note Springer Nature remains neutral with regard to jurisdictional claims in published maps and institutional affiliations.

The original article can be found online at https://doi.org/10.1007/s11229-017-1399-7.

$凶 \quad$ Mark Miller

s1033091@sms.ed.ac.uk

1 University of Edinburgh, School of Philosophy, Psychology, and Language Sciences, Dugald Stewart Building, 3 Charles Street, Edinburgh EH8 9AD, Scotland, UK 